\title{
Construction safety performance assessment on construction site through frequency adjusted importance index in Tangerang Selatan
}

\author{
Ferdinand Fassa $^{1,{ }^{*}}$ and Irma Paramita Sofia ${ }^{2}$ \\ ${ }^{1}$ Construction Engineering and Management, Universitas Podomoro, Jakarta, Indonesia \\ ${ }^{2}$ Universitas Pembangunan Jaya, Bintaro, Tangerang Selatan, Indonesia
}

\begin{abstract}
The construction industry has a huge contribution to economic growth in the world, including Indonesia. Massive urban development occurs as a result of significant population growth. Along with the rapid development, safety issue in the construction site is often neglected. In 2017, there were found that more than 123 thousand cases of construction site accidents have happened. This numbers has increased by almost $20 \%$ compared with the number of accidents in 2016. The purpose of this study is to identify significant safety indicators affecting the construction project in Tangerang Selatan. Based on the literature review, a list of 22 safety indicators was produced. These indicators were used in the questionnaire. The main contribution of this paper is providing safety indicators ranking that affects construction work around Tangerang Selatan. The subject of this research includes contractor and consultant experts who work in construction project around Tangerang Selatan. From the survey, we obtained 41 valid responses which then were analyzed using FAII. As a result, we found that the indicator "the company provides safety training for each worker to act safely" has been considered as the most important safety indicator. It is followed by "the contractor always provides PPE such as helmets, boots, gloves, masks, and other tools that can get me out of an accident". Then the third result is "there are safeguards on the project site; safety signs, fire extinguishers, and security fences".
\end{abstract}

\section{Introduction}

In many countries including Indonesia, the construction industry becomes one of the prominent factors of economic growth. In general, the construction industry contributes approximately $11 \%$ to the Gross Domestic Product (GDP) in developing countries [1]. On the contrary, construction work is solely associated with a certain number of accidents [2, 3]. Some papers have shown that the fatality rate is very high in the construction industry [4-7] . In general, Occupational Safety and Health (OSH) issues are often neglected by all the parties during the construction. There are some indicators which can be considered in

* Corresponding author: ferdinand.fassa@podomorouniversity.ac.id 
measuring the OSH issues. In 2017, there were more than 123 thousand cases of construction site accidents, and it has increased by almost $20 \%$ compared with the number of accidents in 2016. In some literature, safety culture is considered as one way to improve safety performance in an organization and construction site. Safety performance evaluation has significant roles to minimize construction accidents. The objective of this paper is to assess safety indicators performance through observation and survey. A survey questionnaire has been used in this survey. There were 50 stakeholders in four apartment construction projects in Tangerang Selatan were involved.

\section{Literature review}

Some studies have reviewed many various factors that influence health and safety issues. FAII method was used to rank all the indicators that have a significant effect on safety construction factors. The indicator that used in this paper were adopted from a study that collected by Gunduz [8] combine with the indicator issues taken from "Peraturan Menteri PU No. 05/PRT/M/2014". As a result of the combination, there were 22 indicators which have significant influences in safety and health performance. There are several causes of construction accidents can be associated with the characteristics of the construction industry. Specific attributes such as heavy equipment, working environments, and the variety of jobs can turn a construction site becomes a dangerous place to work. From a study by $\mathrm{Yu}$ [9], the indicator "to provide safety training, campaigns, and awareness" were considered as one indicator that used in this research. Along with that, the indicator "PPE and Safety Procedure" were also used $[6,10]$. Another indicator is "contractor always conducting safety meeting periodically and safety coordination on site in assessing safety performance $[11,12]$ ". The primary contribution of this paper is to rank the 22 construction project safety indicators in both of their frequencies and importance. Those safety indicators were known by the engineers and construction professionals as the influential indicators that affecting safety in the construction project.

\section{Methodology}

Quantitative research has been carried out in this study, and there were 22 safety indicators adopted from some literature. A survey was prepared to meet the objective of this paper. There are two sections in the questionnaire, the first part is to get the respondent's background information, and the second part is to evaluate the frequency and the importance of the safety indicator. In the first part, all respondents asked to give their information relating with ages, a number of years on work experience and position in the project. The aim for this part is to classify the respondents into a certain level for the comparisons purpose. In the following part of the questionnaire, all respondents were requested to evaluate the "frequency" (how often all the indicators are implemented) and the "importance" (the impact of the safety indicators during the constructions project). All the statements were expressed by using on the Five-point Likert scale ( 1 stand for very low frequency, 2 is for low level, 3 is for moderate level, 4 is for high level, and 5 is for very high). A set of 22 safety indicators is shown in Table 1.

A survey was performed as a data collection method. The questionnaires were distributed to contractors and consultants around Tangerang Selatan. Totally 41 questionnaire's sheets were received from 50 respondents in 4 constructions project. Statistical analyses such as FAII was used in data analysis. In assessing the importance of safety factors, Relative Importance Index (RII) method was implemented in this research. A Likert scale was used to rate the indicators in term of frequency and importance. 
Table 1. List of 22 safety indicators.

\begin{tabular}{|c|c|}
\hline Indicator & References \\
\hline The company provides safety training for each worker to act safely & {$[9,6,13,14]$} \\
\hline Contractor provide safety information/record board & {$[15,11]$} \\
\hline Contractor provide safety team & {$[9,11,16]$} \\
\hline Contractor provide technical guidance & [9] \\
\hline Contractor provides tool box meeting to all workers & {$[9,15,6]$} \\
\hline Contractor always carry out jobsite safety inspection & [9] \\
\hline Contractor always frequent carry out risk assessment & {$[17,13,18]$} \\
\hline $\begin{array}{l}\text { The contractor always provides PPE such as: helmets, boots, gloves, } \\
\text { masks, and other tools that can get me out of an accident }\end{array}$ & {$[9,13,19]$} \\
\hline Contractor always conducting safety meetings & [19] \\
\hline $\begin{array}{l}\text { Owner/contractor always provide reward and punishment for safe } \\
\text { practice and unsafe work }\end{array}$ & {$[11]$} \\
\hline $\begin{array}{l}\text { Contractor always proposed work method for material handling, } \\
\text { storage and transportation }\end{array}$ & {$[20,21]$} \\
\hline Contractor always control and monitor safety behavior of subcontractor & {$[22,23]$} \\
\hline $\begin{array}{l}\text { Contractor always carry out coordination on jobsite through their } \\
\text { safety department }\end{array}$ & [9] \\
\hline Owner/contractor provide emergency planning in jobsite & [9] \\
\hline Owner/contractor provide first aid practice & {$[9]$} \\
\hline Project owner take a participation in safety management & {$[24]$} \\
\hline Owner take job site visits in safety performance & {$[25]$} \\
\hline Owner take meetings in safety performance & [25] \\
\hline Contractor set out working time max 12 hours & [9] \\
\hline Contractor always control safety attitudes and risk taking behavior & {$[26]$} \\
\hline Contractor provide working spaces in safe condition & {$[10,19]$} \\
\hline $\begin{array}{l}\text { There are safeguards on the project site: Safety signs, Fire } \\
\text { extinguishers and security fences }\end{array}$ & [25] \\
\hline
\end{tabular}

All indicators were ranked with Frequency Adjusted Importance Index (FAII) [27, 28]. In order to find the FAII scores, RII and FI (Frequency Index) need to be calculated first. The five-point Likert scale used to measure the frequency of all indicators. FAII formula produces safety indicators ranking due to its combination frequency and importance in one 
formula. Furthermore, the rank for each indicator is calculated based on the following formula:

$$
\begin{gathered}
\text { FAII }=(\mathrm{RII}) *(\mathrm{FI}) \\
(\mathrm{RII})(\text { in percentage })=\left(\sum \mathrm{W}(\text { importance }) / \mathrm{A} * \mathrm{~N}\right) * 100 \\
(\mathrm{FI})(\text { in percentage })=\left(\sum \mathrm{W}(\text { frequency }) / \mathrm{A} * \mathrm{~N}\right) * 100
\end{gathered}
$$

where $\mathrm{W}=$ weight given to each factor by the respondents $(1-5), \mathrm{A}=$ the highest weight (in this case is 5), $\mathrm{N}=$ total number of respondents.

\section{Data characteristics}

This survey aims to investigate the perceptions of respondents on the safety indicators. The questionnaire is composed of two sections: the respondent's information and safety indicator assessment. Respondent's work experience (number of years) in the construction project is categorized into several groups: 0 to 5 years, 6 to 10 years, 11 to 15 years and more than 15 years.

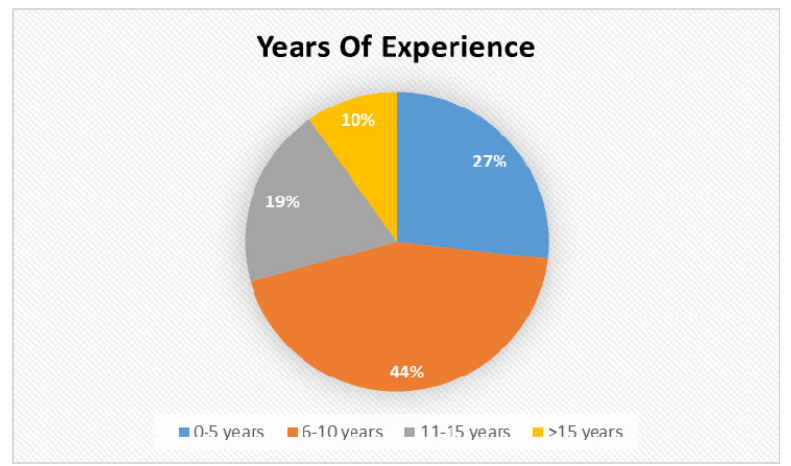

Fig. 1. Number of respondents based on years of experience.

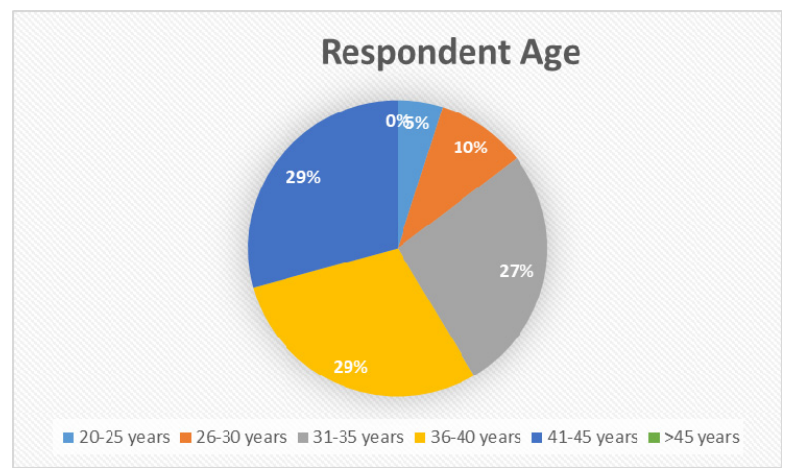

Fig. 2. Respondents' ages.

Fig. 1 shows the percentages respondents' years of experience. From Fig. 1, it can be seen that the proportion of the respondents' year of experience between 6 to 10 years is $44 \%$. Only $10 \%$ of the respondents have more than 15 years of experience.

Fig. 2 presents the percentages of respondent ages who take part in the survey. From Fig. 2, there were $29 \%$ of the respondents between the age of the $36-40$ years old have par- 
Table 2. Ranked safety indicators based on FAII method.

\begin{tabular}{|c|c|c|c|c|}
\hline Safety Indicators & RII & FI & FAII & Rank \\
\hline $\begin{array}{l}\text { The company provides safety training for each worker to } \\
\text { act safely }\end{array}$ & 89.8 & 87.8 & 78.8 & 1 \\
\hline $\begin{array}{l}\text { The contractor always provides PPE such as: helmets, } \\
\text { boots, gloves, masks, and other tools that can get me out } \\
\text { of an accident }\end{array}$ & 88.8 & 88.30 & 78.4 & 2 \\
\hline $\begin{array}{l}\text { There are safeguards on the project site: Safety signs, } \\
\text { Fire extinguishers and security fences }\end{array}$ & 86.8 & 82.9 & 72.0 & 3 \\
\hline Owner/contractor provide first aid training & 87.8 & 82 & 72.0 & 4 \\
\hline $\begin{array}{l}\text { Contractor provide site layout and working spaces in safe } \\
\text { condition }\end{array}$ & 85.4 & 83.9 & 71.6 & 5 \\
\hline Contractor provide technical guidance & 88.3 & 80.5 & 71.1 & 6 \\
\hline Contractor provide safety team & 85.4 & 82.9 & 70.8 & 7 \\
\hline Contractor always carry out jobsite safety inspection & 84.9 & 85.9 & 68.7 & 8 \\
\hline Contractor provide safety information/record board & 85.4 & 79 & 67.5 & 9 \\
\hline $\begin{array}{l}\text { Contractor always control safety attitudes and risk taking } \\
\text { behaviour }\end{array}$ & 82 & 81 & 66.4 & 10 \\
\hline Contractor always conducting safety meetings & 82.9 & 80 & 66.3 & 11 \\
\hline Contractor always frequent carry out risk assessment & 76.1 & 85.9 & 65.3 & 12 \\
\hline $\begin{array}{l}\text { Owner take participation in safety management during } \\
\text { project execution }\end{array}$ & 79 & 80 & 63.2 & 13 \\
\hline Owner/contractor provide emergency planning in jobsite & 83.4 & 75.1 & 62.7 & 14 \\
\hline Contractor provides tool box meeting to workers & 81.5 & 75.1 & 61.2 & 15 \\
\hline Contractor set out working time max 12 hours & 75.1 & 80 & 60.1 & 16 \\
\hline $\begin{array}{l}\text { Owner/contractor always provide reward and punishment } \\
\text { for safe practice and unsafe act }\end{array}$ & 80.5 & 73.2 & 58.9 & 17 \\
\hline $\begin{array}{l}\text { Contractor always carry out safety coordination on } \\
\text { jobsite through safety department and committee }\end{array}$ & 82 & 70.7 & 58 & 18 \\
\hline $\begin{array}{l}\text { Contractor always proposed work method for material } \\
\text { handling, storage and transportation }\end{array}$ & 76.6 & 72.2 & 55.3 & 19 \\
\hline Owner take meetings for safety performance & 72.7 & 74.6 & 54.2 & 20 \\
\hline Owner take job site visits for safety performance & 71.1 & 71.1 & 51.4 & 21 \\
\hline $\begin{array}{l}\text { Contractor always control and monitor subcontractors } \\
\text { safety behavior }\end{array}$ & 76.1 & 66.8 & 50.9 & 22 \\
\hline
\end{tabular}


ticipated in this survey. It is as high as the proportion of the age of 41-45 years old. It was also shown that $27 \%$ of the respondent's age between $31-35$ years old is the second most common ages. From these result, we can conclude that most respondents were on their productive ages when participated in this survey.

\section{Statistical data analysis}

Table 2 shows the FAII calculation from all the questionnaire responses. After assessing all the ranks in Table 2, it can be concluded that "The company provides safety training for each worker to act safely" as the top rank in safety indicator and it is followed by "The contractor always provides PPE such as helmets, boots, gloves, masks, and other tools that can get me out of an accident" as the second most common. On the other hand "Contractor always control and monitor sub-contractors safety behavior" is the least significant indicator that affects safety in the construction project at Tangerang Selatan.

\section{Conclusions}

This paper focuses on identifying the safety indicator that affecting the construction project in Tangerang Selatan. A set of questionnaire was distributed in several construction projects. The main contribution of this study is to rank the importance of safety indicators. From the FAII analysis result, it can be summarized that these indicators: (1) The company provides safety training for each worker to act safely, is the top rank in safety indicator; it is followed by (2) The contractor always provides PPE such as helmets, boots, gloves, masks, and other tools that can get me out of an accident, as the second most common factors that affect safety in construction project. The result of this paper will be beneficial for all stakeholder in the construction industry to identify critical safety factors in the construction project.

\section{References}

1. G. T. H. Dang, L. S. Pheng, Habitat International 35, 1 (2011)

2. G. M. Waehrer, X. S. Dong, T. Miller, E. Halie, Y. Men, Accident Analysis and Prevention 39, 6 (2007)

3. R. Sacks, O. Rozenfeld, Y. Rosenfeld, Journal of Constuction Engineering and Management 135, 8 (2009)

4. I. H. June, K. Y. Jun, K. S. Geun, K. Y. Kyu, J. Y. Su, L. H. Pyung, Safety Science 47, 8 (2009)

5. C. W. Cheng, S. S. Leu, C. C. Lin, C. Fan, Safety Science 48, 6 (2010)

6. A. Pinto, I. L. Nunes, R. A. Riberio, Safety Science 49, 5 (2011)

7. H. Y. Chong, T. S. Low, International Journal of Occupational Safety and Ergonomics 20, 3 (2014)

8. M. Gunduz, B. Ahsan, International Journal of Industrial Ergonomics 64 (2018)

9. Q. Z. Yu, L. Y. Ding, C. Zhou, H. B. Luo, Accident Analysis \& Prevention 68 (2014)

10. K. Hu, H. Rahmandad, T. S. Jackson, W. Winchester, Construction Management and Economics 29, 4 (2011)

11. M. Hallowell, ASCE Journal of Management in Engineering 28, 2 (2012) 
12. S. A. Haadir, K. Panuwatwanich, Procedia Engineering 14 (2011)

13. Z. Ismail, S. Doostdar, Z. Harun, Safety Science 50, 3 (2012)

14. R. Awwad, O. E. Souki, M. Jabbour, Safety Science 83, (2016)

15. Y. Sun, D. Fang, S. Wang, M. Dai, X. Lv, ASCE Journal of Management in Engineering 24, 1 (2008)

16. E. Sawacha, S. Naoum, D. Fong, International Journal of Project Management 17, 5 (1999)

17. A. Perlman, R. Sacks, R. Barak, Safety Science 64 (2014)

18. M. Hallowell, Construction Management and Economics 28, 4 (2010)

19. Menteri Pekerjaan Umum Republik Indonesia, Peraturan Menteri Pekerjaan Umum No. 05/PRT/M/2014 tentang Pedoman Sistem Manajemen Keselamatan Dan Kesehatan Kerja (SMK3) Konstruksi Bidang Pekerjaan Umum (Menteri Pekerjaan Umum Republik Indonesia, Jakarta, 2014)

20. O. Abudayyeh, T. K. Fredericks, S. E. Butt, A. Shaar, International Journal of Project Management 24, 2 (2006)

21. R. A. Haslam, S. A. Hide, A. G. F. Gibb, D. E. Gyi, T. Pavitt, S. Atkinson, A. R. Duff, Applied Ergonnomics 36, 4 (2005)

22. Q. Chen, R. Jin, Safety Science 74 (2015)

23. S. T. Ng, K. P. Cheng, R. M. Skitmore, Building Environment 40, 10 (2005)

24. X. Huang, J. Hinze, ASCE Journal of Construction Engineering and Management 132, 2 (2006)

25. C. M. Tam, S. X. Zeng, Z. M. Deng, Safety Science 42, 7 (2004)

26. T. Aksorn, B. H. W. Hadikusumo, Safety Science 46, 4 (2008)

27. A. M. A. Yahya, Analysis of Project Success Factors in Middle East Construction Industry (American University of Sharjah, Sharjah, 2014)

28. M. M. Marzouk, T. I. El-Rasas, Journal of Advanced Research 5, 1 (2014) 